\title{
A RECONSTRUCTION OF AFRICA'S POLITICAL CULTURE IN THE PURVIEW OF FULANI HERDSMEN CURRENT MODE OF OPERATIONS IN NIGERIA
}

\author{
Chukwugozie Donatus Nwoye*, Charles C. Nweke*, \\ Jude I. Onebunne* \& Stephen C. Okeke* \\ http://dx.doi.org/10.4314/og.v14i1.5
}

\begin{abstract}
It is an established fact that Nigeria is the most populous nation in Africa. It is equally a common understanding that the internal political dynamics in Nigeria invariably, little or more, have their effects on the general well-being of Africa as a continent. In mind of this strategic position of Nigeria in relation to the majority of African nations, and in the light of the current mode of operation by the Fulani herdsmen in Nigeria; this study argues that a reconstruction of Nigeria's Political Culture, and by extension, that of Africa as a whole is imperative. This is because, just like Nigeria, almost all African nations have the challenges associated with immigration. With the concept of communistic Culture as a proposed solution, it is believed in this study that a cue from it will to a greater extent solve the problems of immigration, that is, majority culture versus minority culture challenges in African nations' corporate existence.
\end{abstract}

Keywords: Reconstruction, Political Culture, Fulani, Herdsmen, Communistic Culture

\section{Introduction}

There is no doubt that the issue of immigration has cut its fair share of discussions in the affairs of the world today. At the centre of these discussions is Africa in relation to Europe and North America in terms of immigrations for greener pastures. But most surprising and worrisome at the same time is the issue of immigration within African soils. With painstaking observation, one perceives that beneath most problems, challenges confronting Africa today are that of conflicts arising from cultural contacts between and within Africans. It is subtly in the form of struggles for domination in the 
Nwoye, Nweke, Onebunne \& Okeke: A Reconstruction of Africa's Political ...

political landscape between immigrant Africans and aboriginal, indigenous Africans. Immigrant Africans in the sense of those Africans who have left their original settlements and come to live in another areas of Africa other than their own due to one reason or the other. And by the aboriginal, indigenous Africans are those who still occupy their original or ancestral homes and playing host to the immigrants. This study asserts that it is the struggle for political domination especially from the immigrant Africans against the aboriginal, indigenous Africans that has hobbled the unity and consequently the desired development in Africa. The situation is compounded by the balkanization that preceded colonialism in Africa; where seemingly incompatible group of people where lumped together against their will to exist together.

In discussing this issue, the discourse will open by articulating the phenomenon of settlement as it pertains to Africa making the statement that some Africans are immigrants and others aborigines, indigenous Africans; and that the former almost always create the conflicts experienced in almost the whole of Africa today due to their inordinate desire for control of political power at the centre. The preceding claim will be buttressed with the activities of Fulani herdsmen's mode of operation in Nigeria. Next, the papers elucidates on how the problem under discussion has affected the political culture of Africans in such a manner that her political culture is an apology of what it ought to be. In furtherance, the paper advocates for inculcation of the entailments of the concept of communistic culture as a way forward. Finally, the discourse ends with summary and conclusion.

\section{Human Settlements in Africa}

In every clime, there are people known to be the original inhabitants, the aborigines. They are so to speak, people who occupied a particular locale before the advent of any other people. That is, they were born and raised there. The place they occupy is said to be their ancestral home. Sometimes they leave the particular place to another due to one factor or the other. It is this movement leading to encounter with others that often result in conflicts and crises moments. In Africa, we have people of this nature. 
Of all the African tribes presently in South Africa, the only truly original indigenous people of the region are the San (Bushman) who were the hunter gatherers and the Nama who lived a semi nomadic pastoral life. Both these groups were part of the Khoikhoi people who, unfortunately, have practically disappeared except for the Nama living in Namaqualand and the very small amount of San people living mainly in Namibia as well as on the South African side of the border with Namibia. All these African tribes are part of the Khoisan Group. These two groups lived in Southern Africa in isolation for Millennia until groups of people started migrating from the north of Africa and with each wave of groups the Nama and San people moved further south with the Nama residing mainly in the Cape Province. Pure Nama people are now very rare as they have been practically eliminated due to intermarriage with other tribes as well as by outbreaks of smallpox during the 18th century. The language spoken by the San and the Nama are Khoisan languages with most of the consonants being click sounds. Today the Nama people can be found mainly in the region of the Richtersveld Cultural and Botanical Landscape a UNESCO World Heritage Site in North Western South Africa where they practice their semi-nomadic cultural lifestyle. They are recognizable by their yellowish skin tones and a slightly Mongolian appearance with high cheekbones. ${ }^{1}$

Furthermore,

The San people today, consist of just a few remnants of these truly indigenous inhabitants of South Africa and their history remains in their paintings and engravings encountered over large portions of South Africa. San or Bushman paintings can be found from the Cape to the Zambezi River in Zimbabwe as well as in Namibia. .... A great example of the San 
Nwoye, Nweke, Onebunne \& Okeke: A Reconstruction of Africa's Political ...

tribe can be seen in the well-known Jamie Uys film "The Gods must be crazy." 2

Equally, we have similar occurrence in West Africa. However, troubles, challenges often result when the immigrants get in contact with aboriginal people and, in most cases, when the immigrants desire to dominate and rule over the aborigines. These contact-challenges also occurred due to political and economic realities of a time especially colonialism in Africa. According to Mohamed Ewanghaye:

The Tuareg, Woodaabè, and Toubou are nomadic peoples in the Sahelo-Saharan countries (Niger, Mali, Chad, Algeria, Libya, and Mauritania). The balkanization of the African continent resulting from the Berlin Conference in 1885 divided these peoples among several different countries, the leadership of which favored other peoples, generally sedentary farmers, who had a vision closer to colonialism and who continued colonial works. Since decolonization, the suffering of the pastoral nomadic peoples has continued. Indeed, the configurations of these countries do not take their specific political, geographical, and cultural features into account at all. In forming these countries, the nomad component was difficult to control, and the solution was either to ignore them or to persecute them until the end. This is why, since then, each group has been trying to resist this steamroller. They want to continue to exist as completely separate entities within their current countries, as they had done for thousands of years before the colonial phenomenon. The armed fights led by Tuareg and the Toubous in Niger and Mali since the early 1990s ended with negotiations under the aegis of France and countries in the sub-region. These negotiations resulted in peace agreements that provided for the nomads' progressive recognition in government bodies. These agreements are being applied, yet the process is far from what we would consider satisfactory. The Ogoni people of Nigeria are faced 
with the same constraints in a country that counts thousands of nations and of peoples, each with its own identity. The Ogoni are a minority, a circumstance complicated even more by the richness of the subsoil of their lands. Their fight is still ongoing in a Nigeria that refuses to recognize the legitimate nature of their aspirations. Opposing them is the machine of the multinationals exploiting the oil in the Niger Delta and a government primarily run by people who are the accomplices of these multinationals in crushing the Ogoni without the world knowing. ${ }^{3}$

From the above, observes that it is the issue of migration coupled with balkanization preceding colonialism that have plunged African continent in the ugly situation it has found herself. Where Africans, both aborigines/indigenous people and immigrants have continued to struggle for workable blueprint for peaceful and harmonious co-existence. And this is worse off where the immigrants intentionally but erroneously lay claim to rights they do not have such as claiming that lands belonging rightfully to others are theirs. This is exemplified with the Fulani tribe found in Nigeria.

\section{Fulani Herdsmen Operations in Nigeria Who are the Fulanis?}

They are nomadic herders, whose origin can be traced to the Futajalon Mountains of West Africa, and whose primary means of livelihood is rearing of livestock. They are thickly found in the Sahel and semi-arid parts of West Africa but due to changes in climatic conditions, many Fulani herdsmen have moved further south into the savannah and tropical forest areas of West Africa. They are found in countries like Nigeria, Niger, Senegal, Guinea, Mauritania, Mali, Burkina Faso, Benin, Cote d'Ivoire and Cameroon. In Senegal, they are found in the northeastern Ferlo and the southeastern parts of the country. ${ }^{4}$

The Fulani people or Fulani or Fulbe are one of the largest ethno linguistic groups in Africa, numbering approximately 40 million people in total. They form one of the most widely dispersed and culturally 
Nwoye, Nweke, Onebunne \& Okeke: A Reconstruction of Africa's Political ...

diverse of the peoples of Africa. The Fulani are bound together by the common language of Fulfulde, as well as by some basic elements of Fulbe culture, such as the pulaaku, a code of conduct common to all Fulani groups. ${ }^{5}$

Taking a cue from the foregoing, one is justifiably filled with the feelings that the Fulani herdsmen are naturally nomadic people who have their elementary means of livelihood as that of raising and tending cattle, and they, itinerantly go from one location to another, from one country to another in search of food for their livestock. Hence, the life, movement of this group of people appears largely dependent on the food (grasses) for their livestock. It is amply clear that the Fulanis are not originally Nigerians from the brief history above. Historically, the Fulanis in Nigeria migrated from Senegal and settled in the Northern part of Nigeria which was originally occupied by the Hausa ethnic group. It was through the Jihad war of 1804, led by Othman Dan Fodiyo, a Fulani, that the Fulanis conquered the Hausa people and got themselves forcefully integrated into a country later called Nigeria. Since then, it has been one skirmish after another as the Fulanis try to dominate and control the affairs of the whole country. This scenario is almost the case in most African countries. And this has been the bane of African unity and development; struggle for political and economic domination especially by group that immigrated to another locale. But this phenomenon was worst in African continent with the balkanization of the continent which preceded colonialism. Different ethnic groups were forced to live together with others they are not compatible with or livable with. And some of these immigrant groups make matters worse when they try to force others especially the aborigines to live a way of life they are not accustomed to, forcefully. A case in point is the Fulani people in Nigeria with their sole agendum of trying to convert the whole of Nigeria to a particular form of life, Islamization. This is abundantly clear with current political dispensation of Nigeria where a Fulani man is at helm of affairs as the head of state. 


\section{Activities of Fulani Herdsmen in Nigeria}

In the current dispensation in Nigeria, the normal activities of Fulani herdsmen have taken an abnormal turn. In the course of managing the herd and driving cattle around, cattle grazing on farmlands have almost always resulted in destruction of crops, hence, a source of terrible conflicts between the farmers and the herdsmen. These events have revealed the unwholesome nature of this category of people and also an indication of a people with presupposed ulterior motives. The Fulani herdsmen armed with sophisticated weapons these days unlike before now attack their target communities at the time they are most vulnerable such as mid-night or on Sundays when they are in their churches, killing people indiscriminately, mostly women and children, burning houses, occupying those houses and the communities and appropriating the looted properties to themselves. All these happenings, in the full awareness and knowledge of the security agencies who have it as their primary responsibility to forestall or stop the acts in their actual process. The happenings confirm the suspicions of most knowledgeable and wellmeaning Nigerians of the plan to force all Nigerians into a particular way of life not agreed upon and accepted by all Nigerians and against the provisions of the constitution of the Federal Republic of Nigeria. The suspicion was much earlier raised by the lopsided appointments of people from Fulani Sunni Muslims into the key security posts in the country. ${ }^{6}$ Some of the States worse hit are:Benue, Taraba, Nasarawa, Plateau, Kaduna, Katsina, Zamfara; having experienced the gruesome attacks by the Fulani herdsmen with heavy toll in human lives and property and the onslaught is not abating. Most terrible and heart-rending is the brutality and impunity with which the assailants carry out their nefarious attacks without regard for the law and the sanctity of life coupled with now evident observations that the security establishments in the country appear largely to be privy to what is going on. It is in the reality of this apparent conspiracy between the security forces and these sponsored criminals that, a former Army General and one time minister of defense in the Federal Republic of Nigeria, Gen. T.Y. Danjuma (rtd) made the following sincerely shocking but revelatory comments:

In this state and, of course, the riverine state of Nigeria, we must resist it, we must stop it. Every 
Nwoye, Nweke, Onebunne \& Okeke: A Reconstruction of Africa's Political ...

one of us must rise up. The armed forces are not neutral. They collude with the armed bandits that kill people, kill Nigerians; they facilitate their movement; they cover them. If you're depending on the armed forces to stop the killings, you'll all die one by one. The ethnic cleansing must stop in Taraba state, it must stop in all the other states of Nigeria. Otherwise, Somalia would be child's play. I ask every one of you to be alert and defend your country, defend your territory, defend your state. You have nowhere else to go. God bless our country. ${ }^{7}$

Before these comments by Danjuma above, an insight, a small one in comparison to what is going, is seen below of the nefarious activities of these bandits. According to Augustine Adah: "From Northwest regarded as the stronghold of the Hausa/ Fulani in Nigeria to the southern part, largely dominated by Christians, the story is the same as both have bitter experiences of attack by armed gangs suspected to be Fulani herdsmen." Continuing, Augustine Adah gives the following insights:

July 2012: Senator Gyang Dantong and the Majority Leader of the Plateau State House of Assembly, Mr. Gyang Fulani were killed while attending the mass burial of about 50 victims of attack by Fulani herdsmen on villages in Barkin Ladi and Riyom local government areas of the state. The two lawmakers were reportedly gunned down at Maseh village in Riyom LGA, where over 50 victims of the attack were being buried. The gunmen reportedly stormed the venue and opened fire on those present, causing more deaths.March 2014: Gabriel Suswam, former governor of Benue State, narrowly escaped death, when his convoy was ambushed by suspected Fulani mercenaries, who engaged his security men in a gun duel at Tee-Akanyi village, Guma local government area of Benue state. Suswam, while addressing the community lamented the endless attacks on the people of the state by Fulani 
herdsmen. April 2015: Attack on Galadima village, Zamfara State by Fulani herdsmen led to the death of about 30 persons. Another attack by the group, led to the death of 200 persons in the state. It was gathered that the attackers numbering over 70, swooped on the villagers who were at a meeting to discuss the security situation in the area. Farmers and villagers in Imo State also have gory tales to tell. Emotions ran high when scores of angry youths of Irete Community in the state, blocked the everbusy Owerri-Onitsha dual carriageway to protest the damnable activities of Fulani herdsmen in their community. June 2015:Fulani herdsmen attacked Motokun village, Patigi Local Government Area, Kwara State. The Oro-Ago community in Ifelodun Local Government Area of the state was also attacked.

Fulani herdsmen attacked Ninji and Ropp villages in Plateau State and killed 27 persons. Also, the same group reportedly murdered about 70 Christians. September 2015: An attack by some Fulani herdsmen on the community of Onitsha Ukwuani in Ndokwa West local government area of Delta State left about three persons dead. According to report, trouble erupted when the herdsmen allowed their cattle to stray into the community farmlands, destroying a lot of crops in the process, in an attempt to protect their farmlands from the suspected herdsmen, the three villagers were killed. Similar attack was carried out against Oghonogbo community, a boundary between Edo and Delta State. A middle-aged woman was raped and subsequently killed by three Fulani herdsmen in Edo state. The woman was accosted by the suspects while returning from farm at Odighi village in Ovia North East Local Government alongside her 18-year-old son. The son was said to have escaped, while she was caught and raped to death. November 2015: The herdsmen invaded Ulaja and Ojeh communities in Dekina 
Local Government Area of Kogi State and killed about 22 men and women who were either on their way to the farm or already in the farm. Similar attack was witnessed in Abejukolo, headquarters of Omala Local Government Area when Fulani herdsmen hacked a couple on their way to the farm down. The Fulani herdsmen kidnapped Olu Falae, National Chairman, Social Democratic Party (SDP) who was Secretary to the Government of the Federation on his 77th birthday by Fulani herdsmen. The police reportedly rescued Falae after paying a ransom of money, although Solomon Arase, the Inspector General of Police, denied the ransom. January 2016: Many people were killed and others wounded as Fulani herdsmen in the early hours of the day unleashed terror on three communities in Jire Local Government Area of Adamawa State. The marauding herdsmen were said to have attacked Ko, Gereng and Ndikajam communities at about 3.30 am shooting sporadically. The Divisional Police Officer, DPO, in charge of Vunokilang Police Station in Girei Local Government Area was among those killed in the attack.February 2016: About 10 persons were reportedly killed in Tom-Anyiin, TomAtaan, Mbaya and Tombu in the Buruku Local Government Area of the state by Fulani herdsmen. David Mark, former Senate President escaped attack when well-armed Fulani herdsmen shot at his convoy during a visit to gauge the amount of damage meted on Agatu Local Government Area by the same Fulani people. Six traditional rulers in Ijebu-Igbo,Ijebu North Local Government Area of Ogun State, raised the alarm over the alleged destruction of farmlands and the rape of women by Fulani herdsmen in the area. The monarchs said activities of the herdsmen and their cattle posed serious threat to security in the area. While the Ijebus were lamenting the rape of their women by Fulani herdsmen, the people of Uzo-Uwani in 
Enugu State were thrown into mourning on the same day when Fulani herdsmen invaded the community killing two people while 19 were declared missing. The herdsmen had earlier struck and killed an 85year-old Tagbo Oguejiofor in Udi Local Government Area of the state. Oguejiofor was working on his farm at Oma Eke in Udi when the suspected herdsmen attacked and killed him. March 2016: Suspected Fulani herdsmen attacked some villages in Agatu area of Benue State, killing no fewer than 50 persons. This attack came few days after President Muhammadu Buhari had directed the setting up of a panel to find out the root cause of the attacks and proffer a lasting solution. This happened barely a week after more than 100 people were killed in the same community and security meeting held by governors of both Benue and Nasarawa States to end the clash. ${ }^{9}$

In April 2018, an attack on a morning Mass at a Catholic church in North Central Nigeria left two Catholic priests and at least seventeen church members dead. It adds to the hundreds killed by herders in the region so far in this year. Police suspect Fulani herdsmen to be behind the shooting rampage at Saint Ignatius Catholic Church in Mbalom, where about 30 attackers also ransacked a burial ceremony and razed down dozens of homes in the community. ${ }^{10}$ In June 2018, over two hundred Christians were murdered in Plateau State by Fulani herdsmen.

With the foregoing tells of woes, one may ask, what is the cause of all these nefarious activities especially since the inception of the current civilian administration in Nigeria? Among other opinions, it is the examined position of this study that the recent activities of this immigrant tribal group in Nigeria have religiopolitical undercurrents. That is, they seek political domination of the entire country by attacking those who are not of the same faith with them in order for the victims to convert to their creed and by so doing be subjects to them both religiously and politically. That is why the targets of these attacks are predominantly Christians. The appointments in security outfits of the country peopled by men of 
Nwoye, Nweke, Onebunne \& Okeke: A Reconstruction of Africa's Political ...

this tribal extraction and the inaction of the government of the day manned mainly by the people of the same extraction to take proactive measures to stop the evil acts testify to the position of this study. It is a pure drive for dominance and control of political power against other ethnic groups that make up Nigeria. These covert and overt struggles among incompatible groups found in a particular locale in Africa have hobbled Africa's quest for unity and development in one way or the other. The fall outs of the undergirding current of incompatibility among different ethnic groups in different states of Africa can be seen in the type of political culture that has almost become the norm in Africa.

\section{Political Culture in Africa}

According to Johnson Ugoji Anyaele, "Political culture may be defined as the attitudes, sentiments, beliefs, ideas and norms that guide the behaviour of the people in a political system. Political culture therefore embraces such things as the history of the political system adopted, people's reactions to election, method of electing their representatives, etc." 11 From the definition above, one can conceptualize the political culture pervading the entire African political landscape. Most African people through their political parties struggle for domination, domination not in terms of outwitting one another with better ideas to move the nation forward but for domination in terms of subordinating others to second class citizens. Most African political parties are ethnic-oriented ones. They rather seek domination of other ethnic groups through the guise of political parties. Sometimes when they form coalition, the coalition most often end when the dominant ethnic group in the coalition begins to manifest its ulterior motives. They only rode on the back of the merger parties to actualize their ethnic-based goals. A good example of this case is Nigeria. Today, it is crystal clear that the leadership of the current political party at the helm of affairs in Nigeria is thick with ethnic-driven goals. Ranging from the nepotistic appointments it has made, anti-graft war channeled against any dissenting voice to outright tacit support to the ongoing ethnic cleansing orchestrated by the Fulani herdsmen. With the victims mostly Christians, it gives credence to the suspicion of islamization of Nigeria. It reminds one of the Hutsi-Tutsi case in Rwanda in the 1990s. 
The political culture in Africa is such that the struggle for political power is not to better the lot of the whole citizenry but for the few individuals especially those in the ruling political party, their cronies, family members, etc. Opposition is highly perceived as enmity that should not be tolerated. That is why the so-called anticorruption agencies established with the apparent and publicized intention of stamping out corruption end up with their main goal being to silence or weaken any form of opposition to the ruling party or government of the day. Political leaders in Africa are mainly consumers. Most of them are not educated enough to be there. But once their people are in power, he or she is automatically engaged whether competent or not. They do not have the intelligence, wisdom and initiatives to introduce new workable ideas to improve and develop the commonwealth of the people. They are political jobbers, opportunists seeking for what to grab for their personal interests. When eventually they are in there, they scramble over the control of already existing means of revenue in terms of natural resources of the State instead of creating more ways of augmenting the extant ones.

\section{Use of Security Agencies for Intimidation and Harassment}

During Elections: It is a common practice in Africa among the politicians to use Army, Police and other paramilitary agencies to conduct elections. They often adduce the reason of orderliness and peaceful conduct for drafting in these agencies into election. But it has come to be known that they use these security agents to intimidate, harass and scare the electorates away in order to do the bid of their masters which often times are the government in power. The security agents especially the Army whose primary responsibility is to ward off external aggression against the state are now used against the citizens they are meant to protect. In this entire anomaly, the electorates experience loss of confidence in these security outfits and they are left in a hopeless situation.

Financial Inducement: It is an open secret in African political culture that politicians influence even the commission responsible for conducting elections not to talk of the general masses who are in dire need of financial help due to the level of poverty in the land. 
Nwoye, Nweke, Onebunne \& Okeke: A Reconstruction of Africa's Political ...

The political class normally cash in on the fact of poverty to lure the hapless masses into voting against their wish. It seems that the political class intentionally leaves the masses in penury so that they can be easily manipulated during elections.

Ritual killings: It has become a frequent item on the news that during electioneering that intended candidates for one political position or the other engage in frantic hunt for their fellow human beings for extraordinary powers that will enable them clear any perceived obstacle on their way to the intended political positions. They consult with different means of supernatural powers like native doctors (Dibia) who will ask them to bring human parts as part of the rituals to be done in order for them to wield extraordinary powers that will see them through to their desired political offices. In this process, innocent human lives are destroyed as kidnapping, declaration of missing persons, discovery of decomposing corpses around secluded areas with one part or the other of these corpses missing or being cut off, go on the increase. All these are in a bid to occupy an elective position. They seek for these extraordinary spiritual forces in order to intimidate and scare their opponents into submission or outright elimination of their lives.

Biased Appointments: It is a common knowledge that in Africa, most times, the electoral umpires are those chosen by the government or political party in power with the tacit understanding that the elections must be conducted to their own advantage. Complaints are common place in Africa to the effect that commissions responsible for elections are not given the independence, empowerment to conduct elections without fear or favour. They are more often than not appointed to do the will of their masters.

The foregoing descriptions of the political culture in Africa show that it is an apology of what it ought to be. And this anomaly is fuelled by lack of proper understanding. It resulted from unwholesome attachment to one's ethnic provenance and subsequent domination instead of belief in the humanity of all Africans. Africans should rather seek and focus on the sense of humanity of the African person irrespective of ethnic differences for unity and development of all. 


\section{Way Forward}

From the foregoing discourse, one easily understands that one of the major challenges confronting Africa as a continent is the issue of disunity among the component units that make up a state in most African countries. This disunity has led to underdevelopment in Africa. The disunity leading to underdevelopment in Africa has been amply shown in the course of this discourse as caused by the struggles for domination especially from the immigrants against the aborigines/indigenous people in a particular geographical location within Africa. This phenomenon of domination in Africa was compounded during the balkanization that preceded colonialism in Africa. With the partitioning of different African people into different states/countries according to the mind of the colonizers regardless of the compatibility of the people within each group, the struggles for domination got worse and complicatedly compounded. This reality is attested to by the fact that some of these African people have belief systems that are quite contrary to others and putting the contraries together in terms of belief system has been a terrible challenge confronting African continent till date.

This is exemplified with the Nigerian scenario where a particular ethnic group, the Fulanis with their Sunni version of Islam, have been struggling since the inception of the country called Nigeria to dominate the entire country in all ramifications with little or no attention to the sensibilities of other ethnic groups making up the country. And their unwholesome desire has left the unity of the country more in jeopardy. It has brought so many ills like mediocrity, nepotism, favouritism, corruption, marginalization, desecration of human lives as they value cows more than human lives, to overall lack of desired development of the country. This situation in Nigeria is prevalent in almost all the countries of Africa, hence, an endemic problem in Africa. It is the same issue that has rendered the political culture of Africa to be an apology of what it ought to be as shown above. This irrational struggle, so to speak, has been so etched in the psyche of most Africans that it seems that the minds of most Africans have been constructed towards such negative direction, irredeemably. The direction of sacrificing anything worthwhile for meaningful unity and development on the altar of tribal/ethnic-driven quest for domination. The direction of not taking into cognizance the humanity of human person to the 
Nwoye, Nweke, Onebunne \& Okeke: A Reconstruction of Africa's Political ...

extent of killing fellow human beings because of hunger for political power and its offal. For Africa to make headway, there is need for reconstruction of the faulty construction in the mind and consciousness of the African person. There is need for the understanding of oneness of all humans irrespective of physical and cultural differences. The understanding that everybody is from the same source of life, and as such, is returning to it in due time will go a long way in re-orienting and reconstructing the thought pattern of Africans guilty of the issue under discourse.

\section{Reconstruction: Communistic Culture}

Communistic qualifying culture in this context is informed by that kernel aspect of communism's definition that says "... commonly owned by a classless society and not by individual citizens". Derivatively, communistic culture posits the idea of equality of all cultures without any culture being tagged inferior and the other superior. This is because, the basis of the unreasonable struggles for domination found in most African countries are premised on the phenomenon of superior versus inferior cultures. And it is normally shown through religion, that is, the claim that a particular religion is the true one and others false, and should be done away with their adherents. Communistic culture posits as well that, irrespective of cultural advancement among the comity of cultures, no culture should be termed primitive and the other refined on the account of cultural comparisons. On what premise then is communistic culture predicated? Communistic culture is a coinage by the researchers to capture the fact that every human being is equal and by extension, every culture, by virtue of equality of every individual. The equality of every individual is excavated from the fact that every human being emerged from the same source, and as such, equal in dignity and paralleled in culture. Communistic attached to culture in this context, again, implies the equality of all cultures without any arrogation of superiority to one culture over another.

The thrust of communistic culture as adumbrated above is to underscore the point that every human being is from the same source in terms of emergence into existence and by that very fact is destined to return to the same source. It therefore connotes, primarily, the idea of equality of all human beings, Africans not being an exception. It equally implies that different cultures are equal, level of 
development or richness notwithstanding. If this understanding is etched on African minds, it therefore means that arrogation of cultural superiority which is the primary cause of the whole problem will be minimized if not entirely eliminated. (Some people feel that their own way of life, culture, is the best, hence, they have to impose it on others: cultural superiority. This is usually conveyed through the conveyor belt of religion. This phenomenon is seen largely to be behind most conflicts in Africa though almost always subtle in nature.) With Africa as a reference point in this discussion, it calls for Africans understanding among themselves that no one is superior to the other person, culture inclusive. That having found ourselves in a particular locale, whether by our own design or not, that we should agree amongst ourselves on best ways to co-exist harmoniously for the betterment of all. There is need to cultivate the culture of seeing interests from general instead of particular powered by tribal/ethnic gains. With this understanding, African political culture stands reconstructed and can be restored unto the path of genuine politicking characterized by the advancement of better ideas for the unity and development of specific states/countries and the continent in general.

\section{Summary and Conclusion}

This study opened by asserting that the political culture of the African people is an apology of what it should be. This is informed by the undue struggles by the immigrant Africans - that is, Africans leaving their original African settlements due to one factor or the other (like balkanization that preceded colonialism) and meeting other Africans in their own aboriginal, indigenous settlements trying to dominate the aboriginal/indigenous African in the political arena powered by tribal/ethnic-driven interests of the immigrant Africans and not for the whole interest of Africans in a particular African state. This study exemplified this claim with the current mode of operations by the Fulani herdsmen in Nigeria. Having made the assertion, the study unfolded further by painting the picture of human settlements in Africa. It connects the issue of settlement with the fact that Fulani people are immigrant settlers in Nigeria. Done with describing the nefarious activities of Fulani herdsmen in Nigeria with their suspected plan of political domination of Nigeria through Jihadism, the study as well pointed out the ugly nature of 
Nwoye, Nweke, Onebunne \& Okeke: A Reconstruction of Africa's Political ...

political culture in Africa seeded by parochial interests instead of general interests. It moved further to seek solutions to the problem with the caption, way forward. In it, the researchers call for the reconstruction of African minds with the concept of communistic culture.

In conclusion, this study is of the view that with the bowel of communistic culture offered in the equality of all Africans by the virtue of emergence of all from the same source, that the issue of cultural superiority which is the cause of the conflicts would be minimized if not eliminated entirely. It is when Africans see themselves as human beings equal in being and culture regardless of perceived differences that they can seek the values that promote the interests of all and not the ones fuelled by particular tribal/ethnic inclinations.

\section{*Chukwugozie Donatus Nwoye, PhD}

Chukwuemeka Odumegwu Ojukwu University, Igbariam Campus cd.nwoye@coou.edu.ng

\section{*Charles C. Nweke, PhD}

Nnamdi Azikiwe University, Awka

nkesun2002@yahoo.com

\section{*Jude I. Onebunne, PhD}

Nnamdi Azikiwe University, Awka juno_anyi@yahoo.com

\section{*Stephen C. Okeke, PhD}

Nnamdi Azikiwe University, Awka

stokeketickler@yahoo.com 


\section{References}

1. http://www.thesouthafricaguide.com/africantribes/south-africa-tribes-south-african-culture-thenama-and-san-people/Accessed 19/7/2018

2. Ibid.

3. https://www.culturalsurvival.org/publications/culturalsurvival-quarterly/brief-history-indigenous-peoples-westafrica. Accessed 19/7/2018

4. Chukwugozie Donatus Nwoye and Ughaerumba Ugo A.C, "Fulani Herdsmen in Nigeria: Implications for the Country" NOCEN International Journal of Arts and Social Sciences Maiden Edition Vol.1. No.2, September, 2017 , p. 365.

5. Ibid.

6. punchng.com/southern-groups-knock-buharis-pro-northsecurity-appointments Accessed 13/7/2017

7. Sylvanus Viashima, "Defend yourselves" Sunday Sun March 25, 2018, Vol.14, No. 779, p.48.

8. https://independent.ng/diary-fulani-herdsmen-attack-acrossnigeria/March20,2016 Accessed 20/7/2018

9. Ibid.

10. https://www.christianitytoday.com/news/2018/april/nigeriafulani-attack-catholic-church- benue-boko-haram.html Accessed 20/7/2018

11. Johnson Ugoji Anyaele, Comprehensive Government for Senior Secondary Schools. (Lagos: A Johnson Publishers, 2003), p.14. 